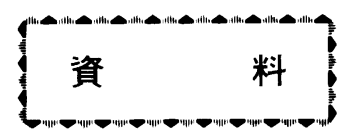

\title{
小型・薄型化の視覚情報表示用光源の開発動向 ${ }^{\dagger}$
}

\author{
IF. 会 員 細谷 勝幸*
}

\section{1.はじめに}

光を利用した視覚情報表示装置の範用は，誘導灯から現 在脚光をあびている液晶デバイス用のバックライトまで多 岐に旦ると考元られる。また，より広義に考えればFAX， P P C (普通紙複写機) などの OA 機器用の光源も含まれ るといえよう．ここでは最近の社会動向から脚光を浴びて いる情報機器用光源（一部その点灯回路を含む）, 新しい AV (オーディオ・ビジュアル) 家電に関連する光源につ いてその動问を述べる.

\section{2. 家電関連商品の動向とその光デバイス}

情報通信やコンピュータ技術の発達により, 従来の家電 製品から情報家電といわれる商品やパーソナルユースの情 報通信機器やコンピュータがすでに一般家庭に入りはじめ
ている。

図 $1^{11}$ は, 読者のアンケート調查により「日経エレクト 口ニクス (日経 BP 社)」がまとめた近未来の今後期待さ れる商品である.

この中でパソコンや家庭向け情報端末，カラー動画テレ ビ，車載用ナビゲーションシステム，壁掛けテレビ八イビ ジョンテレビ, カメラ一体形 VTR など多くの商品に光源 及び光を利用するデバイスが組み込まれることは現在の商 品から容易に推定される.

このよらな動向を端的に反映しているのが，平成 3 年度 (第 24 回)照明学会創立 75 周年記念全国大会の講演内容 ${ }^{2)}$ であろら。「液晶表示とバックライト」のシンポジウム が組まれ，一般講演も含め 187 演題中 17 演題が液晶表示 用バックライトや液晶プロジェクタ一用光源及び OA 機器 の読み取り用光源などであった.

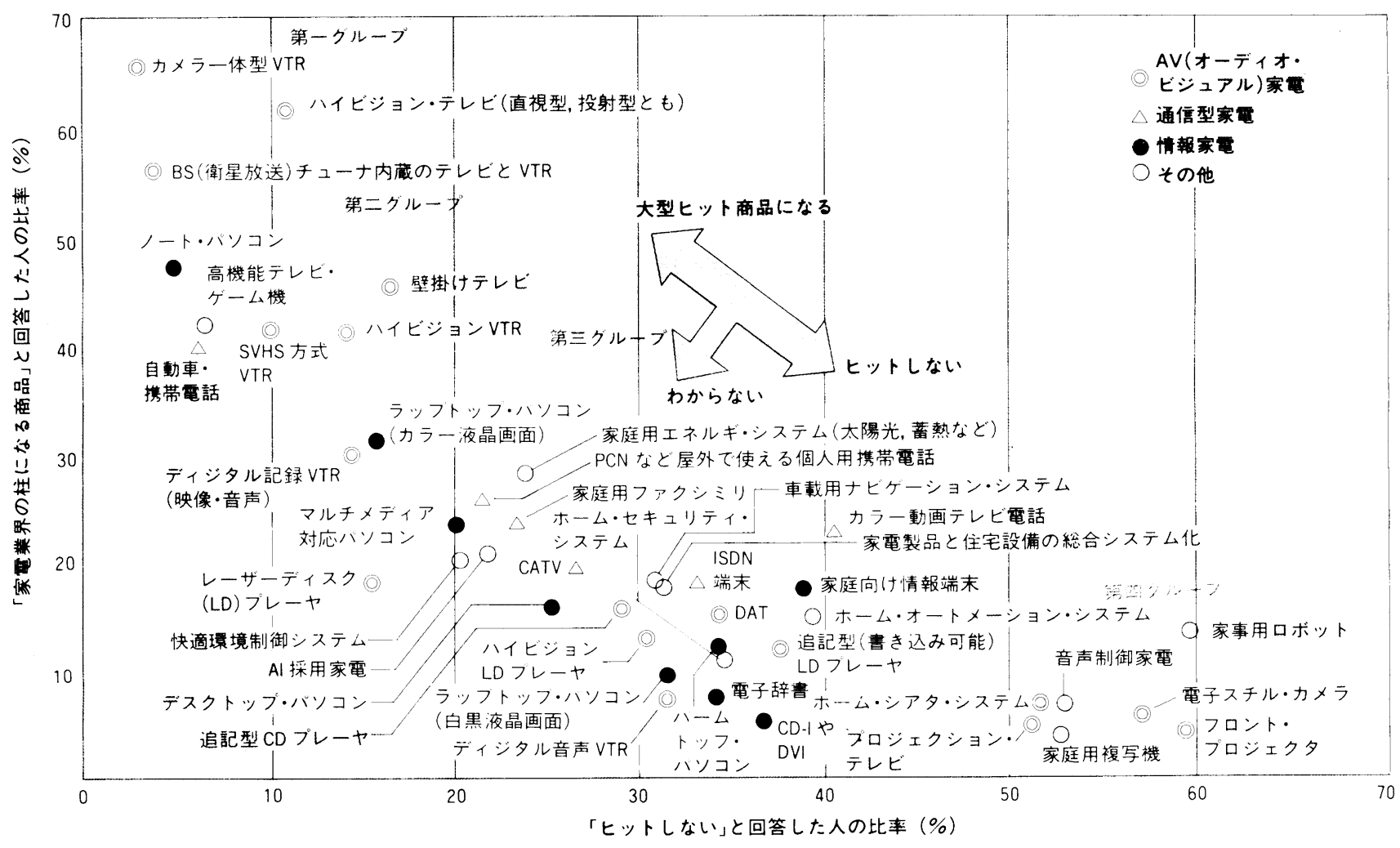

图 1 个後则待さ礼る陮品

+ Trends of compact lighting devices for visual information equip

ments.

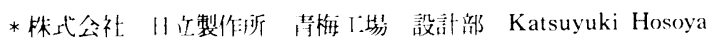

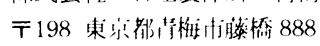


今後期待される商品で紹介した商品に使用されるディス プレイは, 表示品位, 形状 (薄形化), LSI 駆動が容易で

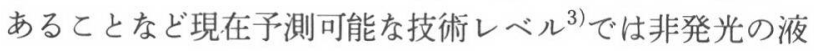
晶 $\left(\mathrm{LCD}^{*}\right)$ が最有力である. 非発光の液晶を平面ディス プレイとして使用するため効率のよい，平面ディスプレイ 飞適した薄形, 白色で色再現性のよい光源デバイス(いわ ゆるバックライト）が必要になる。バックライトとして は, FL (蛍光ランプ), EL（エレクトロルミネッセン ス), LED (発光ダイオード) などがあるが，効率よく白 色光をえられ，寿命の面でも実用に耐えるのは FLである 5.

\section{1 巣光ランプの使用例}

パソコンやワードプロセッサ, 液晶テレビ等に使用され る蛍光ランプは, いわゆる反射方式 (図 2 ) と導光体方式

(図 3 ) の 2 種類に大別されている゙）。を，カメラ一体 形 VTR のビューファインダに使用される液晶用として小 形（1インチ）の平板形蛍光ランプ（図4）が使用されて レる(4)5.

\section{2 液晶投射形ディスプレイ用の光源}

高画質, 大画面のディスプレイやテレビ用として従来の CRT (ブラウン管) 方式にかわる液晶投射形がすでに商 品化されている. 図 5 はフロント（前面投射）方式 ${ }^{6)}$, 図

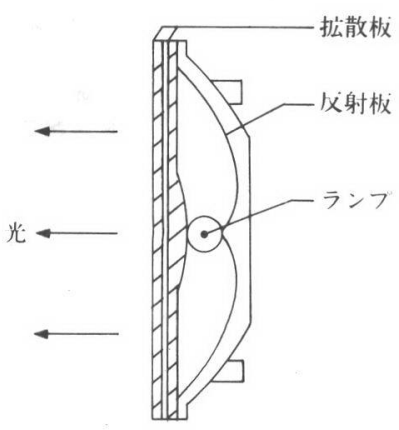

図 2 反射方式照明

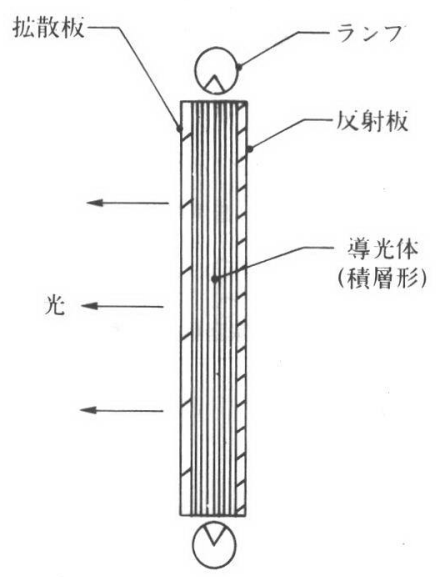

図 3 導光体方式照明

*Liguid Crystal Display

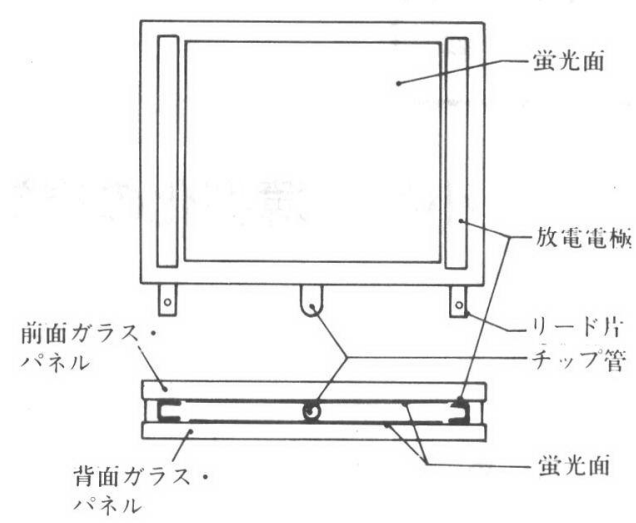

図 4 平板形蛍光ランプの構造例

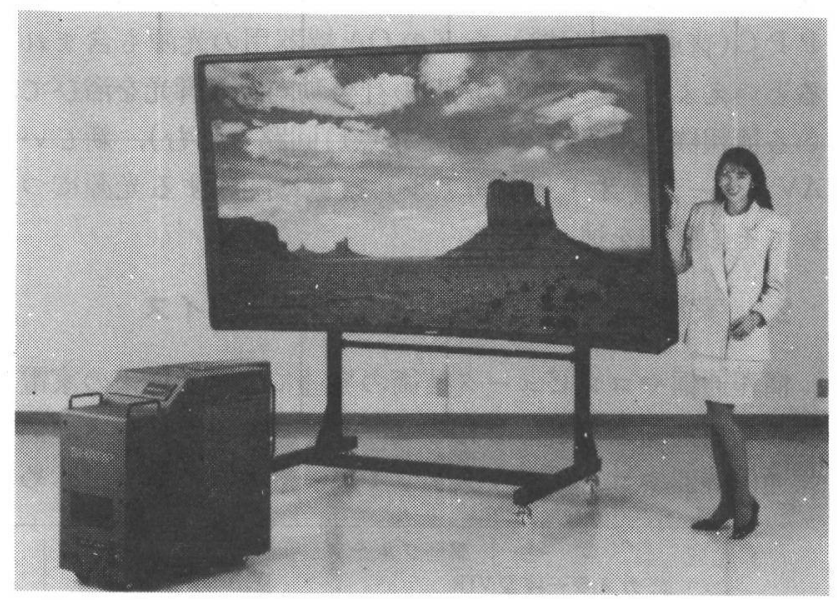

図 5 フロント（前面投射）方式の液晶投射形ディスプレイ

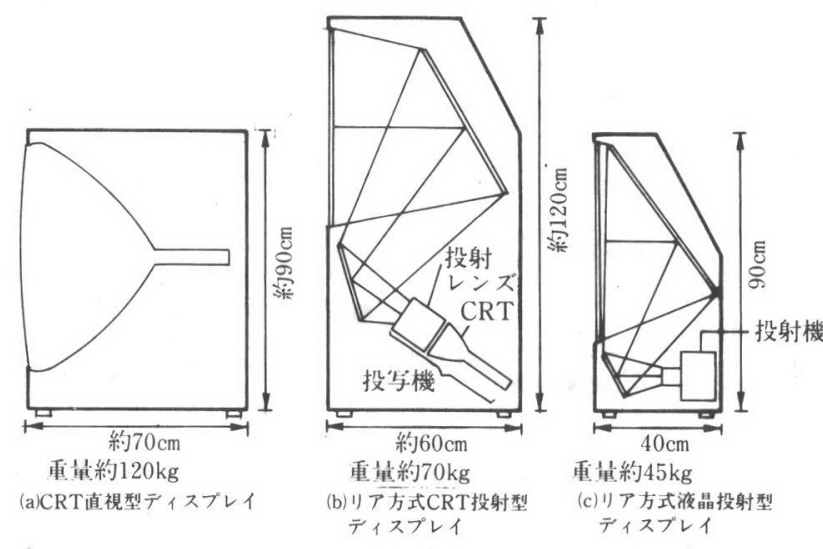

図 6 リア（背面）方式の液晶投射形ディスプレイと CRT 方式の比較 (40インチでの対比例)

6 はリア（背面投射）方式によるCRTとの対比を示した もの ${ }^{7)}$ であ. これらには, 色再現性がよく, 集光しやす い発光体の小さい光源としてハロゲンランプの 250 $\mathrm{W} \sim 300 \mathrm{~W}$, メタルハライドランプの $150 \mathrm{~W}$ が使用されて เる

\section{3 光源の動向}

(1) 液晶バックライト用蛍光ランプ 
表 1 液晶の種類と使用光源

\begin{tabular}{|c|c|c|}
\hline 液 & $\mathrm{S} \cdot \mathrm{T} N$ (白黒) & T F T （カラー） \\
\hline 液晶の透過车 & 約 1596 & 約 396 \\
\hline 使用光源の例 & 冷陰極ランプ & $\begin{array}{l}\text { 命陰極ランプ×多灯 } \\
\text { 又は熱陰極ランプ }\end{array}$ \\
\hline
\end{tabular}

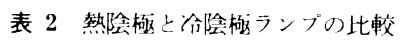

\begin{tabular}{|c|c|c|}
\hline & $\begin{array}{c}\phi 8 \text { 熱陰極ランプ } \\
(\text { HFL08・260EXD80) }\end{array}$ & $\begin{array}{c}\phi 5.6 \text { 冷陰極ランプ } \\
(\mathrm{CFL} 056 \cdot 260 \text { EXD80) }\end{array}$ \\
\hline 寸 法 $(\mathrm{mm})$ & $\phi 8 \times 260$ & $\phi 5.6 \times 260$ \\
\hline ランプ電流 $(\mathrm{mA})$ & 60 & 5.5 \\
\hline ランプ電力 $(W)$ & 5.1 & 1.9 \\
\hline 全 光 束 $(\ell \mathrm{m})$ & 325 & 78 \\
\hline ランプ効率 $(\ell \mathrm{l} / \mathrm{W})$ & $64(156)$ & $41(100)$ \\
\hline
\end{tabular}

現在使用されている液晶は, 大きく戦純マトリックスの S-TN (Super Twisted Nematic) 液晶とアクティブマト リックスのTFT (Thin Film Transistor) 液晶に分けら れ，表 1 に示すよらな透過率の差がある.このため, バッ クライトとして使用される省光ランプの種類や灯数も異な る（表 1 参照）. 一方, 冷陰極䖢光ランプと熱陰歌蛍光ラ ンプでは，その放電特性から表 2 に亦すような基本的な特 性の养があり る. 寸なわち, 液鼠の透過摔が高いS-TN夜晶には効率 は低いが寿命の長い泠㓌極ランプが使用され，透過率の低 いTFT 液晶には冷陰極ランプの多灯か効率の高い熱㓌極 ランプが使用されている.

$$
\text { パーソナルュースのワードプロセッサやパソコンは, }
$$

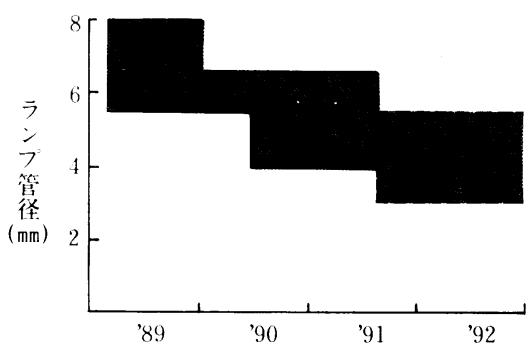

図 7 冷㓌極ランプ細径化の動向

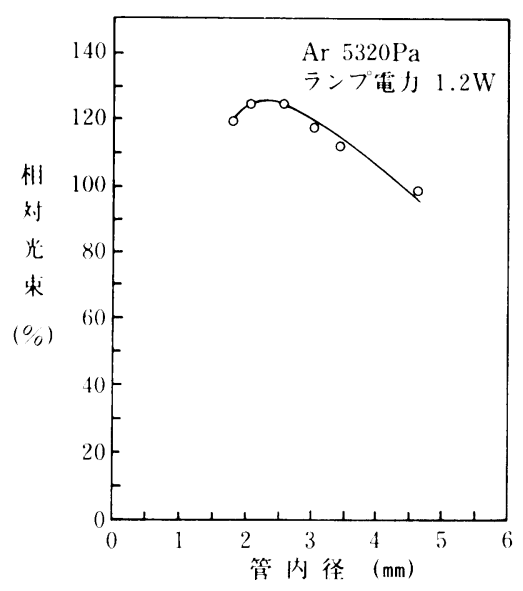

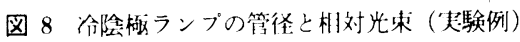

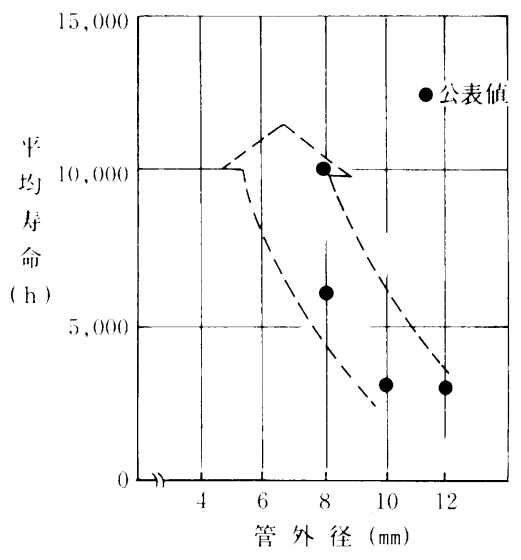

図 9 熱陰極ランプの長寿命細径化の動向

S-TN 液晶の使用が压倒的に多く, 冷陰極ランプを導光体 方式で使用されている．駆動回路を含む液晶モジュールの 薄形化に上もない，パソコンやワードプロセッサはディス クトップからラップトップさらにノート形へと薄形, 軽量 化が急速に進んでいる，このニーズに応えて冷㓌極ランプ の細径化とその効率の検討 ${ }^{9)}$ が進められている. 図 7, 図 $8^{9)}$ に近年の細径化の動向と効率の検討例を示す.

TFT 液晶に使用されている熱陰極ランプの欠点は, 冷 陰極ランプに比べて寿命が短いことであった．近年電極の 改良や点灯回路との最適な組合せ等により寿命が大幅に改 善されてきている 管径の細径化の検討も進められている。乙れらの動问をま とめると図9のとおりである.

この他に，アナログメータ用に視認性を重視した冷㓌極 ランプとして超細径（外径 $2.4 \mathrm{~mm}$ ）で管外壁に導電電極 を有する車載メータの指針用などに使われる蛍光ランプ10) や蛍光ランプ特有の低温始動特性を改善するメッシュ状

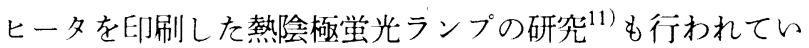
る.

また，パソコンやワードプロセッサの薄形化のニーズか ら蛍光ランプだけではなく, その点灯回路(インバータ)の 薄形, コンパクト化も大をな動向であり, 令陰極ランプ 1 灯 用では厚さ $6 \mathrm{~mm}, 5.5 \mathrm{~mm}$ のものが発表されている ${ }^{1213)}$.

以上，液晶バックライト用としての蛍光ランプ，その点 灯回路の主な動问を記したが，今後課題として次のよらな 点が考えられる.

（亿）冷陰極ランプの細径化は，寿命特性一の影響や，取 扱い上の機械的な強度，さらには量産性の点などからほぼ

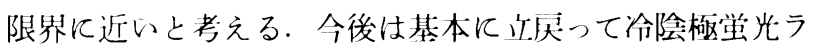
ンプの众点である発光効㻭の改善（低消費電力化）が大き な課題であろら.

(口) 熱陰極蛍光ランプは，まだその寿命特性の改善と細 径化のニーズが大きく，その研究，開発がまだまだ進展す るものと考える.

これらの課題も, 液晶の技術開発や液晶を使用した商品 の動向によっては大をな影響を受けるものと考える。 
(2) 液晶投射形ディスプレイ用光源

液晶投射形ディスプレイがまだ商品化の緒についたとと ろであり, 光源の選択や液晶パネル及び光学系全体との整 合性などシステム全体の課題も多いと考える.

光源に要求される基本的な性能は,

\section{(1)高輝度}

(2)発光体が小さく, メタルハライドランプの場合には放 電の安定性が強く要求される。

(3)高効率

(4)色再現性に優れた発光スペクトル

(5)長寿命

(6)始動時間が短い

(7)小形, 軽量な点灯回路

などである

この液晶投射形ディスプレイは，AV家電あるいは情報 家電の商品として大きi伸びる可能性が大きく，その光源 と点灯回路の研究開発が今後数年で大をく進展するものと 考える.

\section{3. おわりに}

光を利用した視覚情報表示装置の中で, 視在急激にその 用途, 需要が拡大している液晶応用商品に使用される光源 について概説した. 液晶及びその周辺技術の研究, 開発も まだまだ進展が予想され，それによって光源の種類や使用
方法も変わる可能性もあると考えられる. しかし, 現在光 、源やその点炊回路等に要求されている基本的性能や動向を 大きく変えるとは考えられず, 液晶及びその周辺技術分野 と十分な連携をとって光源, 点灯回路の研究開発を進めて ゆくことにより十分そのニーズに対応できるものと考え る.

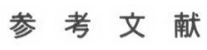

(1) 日経エレクトロニクス No.531（1991.7.8）

(2) 照明学会 : 平成 3 年度照明学会創立 75 周年記念全国大会 講演予原稿集

(3) 照明学会 : 光源システムの技術動向と展望 (1990. 3)

(4) 日経 BP 社：フラットディスプレイ 1990

（5）岸本他：冷陰極形フラット蛍光ランプ 照明学会光関連材 料・デバイス研究会資料 (1988.11)

(6) 電波新聞 1991.6.20

(7) 日経 BP 社：フラットディスプレイ 1991

(8) 小川：照学全大 (平 3 )

(9) 井関他：照学全大 (平 3 )

(10) 高木他：超細管蛍光ランプの特性 照明学会研究会資料 MD-90-38-42

(11) 仁技他：照学全大 (平 3 )

(12) 電波新聞 1991.9. 19

(13) 電波新聞 1991.9.26

（受付 1991 年 11 月 18 日）

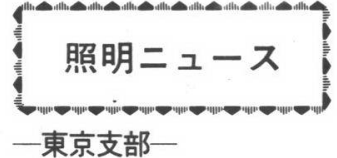

一東京支部一

技術セミナー「色彩学の基礎とその応用」開 催される

東京支部の定例の技術セミナーが, 10 月 8 日（火） TEPCO ホールにて開催された.

今回は，テーマである色彩学を「色はどらして見えるのか」 (矢口博久君)，「色の測り方と表し方」(小松原仁君)，「ょり 良い色のための照明」(渕田隆義君),「写真, 印刷, テレビの 色」(鈴木恒男) の 4 題にわけ，人間が色を感じるメカニズム， 現在広く用的れている表色系, 測色系などの色彩学の基礎か ら, 照明と色の関係, さらには画像システムムおける色再現に 至る応用分野までを，分かりやすく解説して頂いた。

このテーマは, 色彩情報と色の見え研究調査委員会の 3 年間 の調査研究が平成 3 年 3 月几終了し, その集大成である「色彩 情報と色の見六研究調査委員会報告書」を基飞企画された. 最 近の色に対する関心が高まっているとともあって, 若い人を中

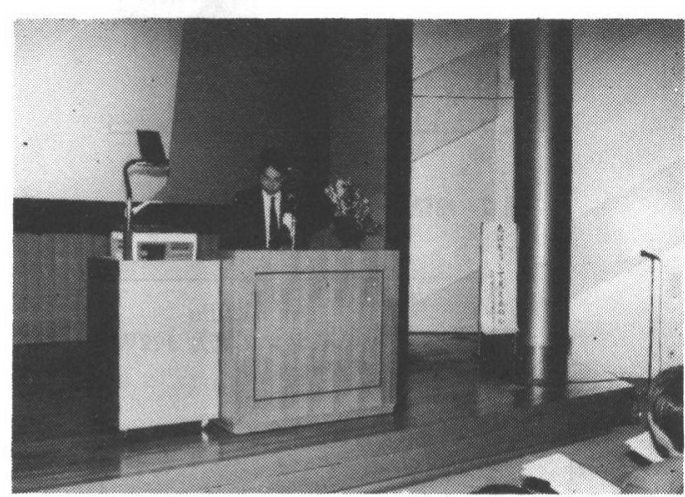

心に 110 名もの参加があり, 成功裡に終了した.

なお，同研究会報告書は，学会事務局にて頒布されることに なっている.

（東京支部庶務幹事 川上 幸二） 